\title{
Feasibility analysis of a hybrid auxiliary power unit for pleasure boats
}

\author{
Lorenzo Ferrari $^{1 *}$, Guido Francesco Frate $^{1}$, Romano Giglioli ${ }^{1}$, Alessia Girolami ${ }^{1}$, Gianluca \\ Pasini $^{1}$ and Federico Tocchi ${ }^{2}$ \\ ${ }^{1}$ University of Pisa, DESTEC - Largo Lucio Lazzarino, 56122 Pisa, PI, Italy \\ ${ }^{2}$ Sanlorenzo s.p.a. - Viale San Bartolomeo, 36219126 La Spezia, SP, Italy
}

\begin{abstract}
To reduce the pollutant emissions in the naval sector, the use of alternative fuels and new power generator systems are both promising solutions. In this study, the feasibility of replacing a pleasure boat Auxiliary Power Unit (APU) with a hybrid solution is studied from the economic and technical points of view. Several power generation technologies and layouts are considered. Many configurations were investigated, from hybrid battery/diesel generator to innovative layouts including fuel cell with onboard Liquified Natural Gas (LNG) reforming for hydrogen production. Since hybrid APUs may yield significant advantages in terms of both environmental and noise pollution, the opportunity of operating the system for several hours without powering up the traditional generators is also considered. For each configuration, $\mathrm{CO} 2$ and NOx emissions, purchasing and operating costs, as well as weight and volume, are estimated. Emissions may be reduced up to $20 \%$ and $60 \%$ for $\mathrm{CO} 2$ and NOx, respectively, and fuel cost reductions up to $35 \%$ may be achieved.
\end{abstract}

\section{Nomenclature}

$\mathrm{AC}$ - Alternating current

CA - Cost analysis

CAPEX - Capital Expenditure

CRF - Capital recovery factor

DC - Direct current

FC - Fuel cell

FCS - Fuel cell system

FE - Full electric

GT - Gross tonnage

ICE - Internal combustion engine

IMO - International maritime organization

LHV - Lower heating value
LNG - Liquified natural gas

MDO - Marine diesel oil

MEPC - Marine environment protection committee

NOx - Nitrogen oxides

PCS - Power conversion system

PEMFC - Proton exchange membrane fuel cell

PEMS - Power and energy management system

SMR - Steam methane reforming

SoC - State of charge

SOx - Sulphur oxides

* corresponding author: lorenzo.ferrari@unipi.it 


\section{Introduction}

The International Maritime Organization (IMO) with Annex VI of the International Convention for the Prevention of Pollution from Ships (MARPOL) sets strict limits on $\mathrm{SO}_{\mathrm{x}}$ and $\mathrm{NO}_{\mathrm{x}}$ emissions [1] especially with Regulation 13 for Nitrogen oxides $\left(\mathrm{NO}_{\mathrm{x}}\right)$ and Regulation 14 for Sulphur oxides ( $\mathrm{SO}_{\mathrm{x}}$ ). In May 2019, IMO's Marine Environment Protection Committee (MEPC) undertook a strategy aimed at 50\% reduction of greenhouse gas emissions from ships in 2050 in comparison to 2008 levels [2]. Nowadays, all pleasure boats sailing all over the world are equipped with medium-high speed compression ignited engine fueled with Marine Diesel Oil (MDO). In particular, for pleasure boats above $24 \mathrm{~m}$ and below 500 GT (gross tonnage), onboard power generation is split between propulsion and all the other services by using different internal combustion engines (ICEs), as reported in Figure 1.

Hybrid systems for storage and generation of electricity help keeping the balance between power generation and demand in the electrical systems, especially when production and/or load are highly variable and stochastic [3]. Short term electrical storage can be profitably adopted by using electrochemical storage systems and supercapacitors [4].

Over the past few decades, many studies investigated shipboard micro-grids due to their complex architecture and high power sources with intermittent loads [5]. Modern shipboard microgrids pose similar issues to those of isolated rural microgrids. Unlike rural communities, pleasure boats are subjected to stringent mass and volume limitations, which may further discourage the adoption of alternative power production and storage technologies.

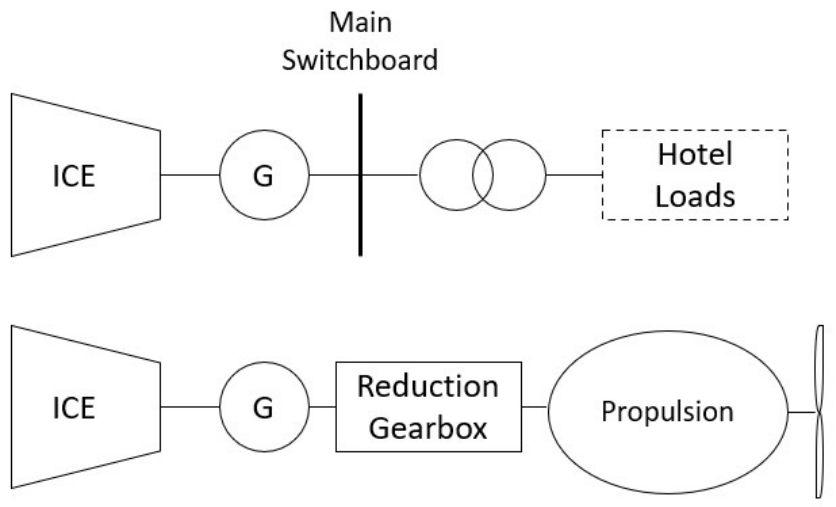

Fig. 1. Conventional shipboard power generation system.

Many past studies investigated the use of Liquified Natural Gas (LNG) as a fuel for ship propulsion [6-8] with a particular focus on technical feasibility and life cycle analysis. These studies found that fuel efficiency may increase by $2 \%$, and the emissions may be reduced to $80 \%$ for $\mathrm{NO}_{\mathrm{x}}$ and $100 \%$ for $\mathrm{SO}_{\mathrm{x}}$ [9]. LNG could also be used for energy recovery from its regasification [10]. Nowadays, the number of LNG-ships is rapidly increasing due to the lower cost of LNG compared to MDO. Many authors analyzed the use of hybrid systems for propulsion and service/hotel loads in vessels. These systems generally include a diesel generator combined with a lithium-ion battery. Results demonstrated that the hybrid system could yield fuel savings around $7 \%$ in comparisonto a standard system [11].

Fuel-cell technology has been recently implemented in military submarines, commercial ferries and offshore support vessels. Similarly, fuel cell power systems are starting to be used, or being programmed, for cruise ships and other marine applications [12-13]. However, 
storing pure hydrogen onboard may cause safety and technical issues in terms of volumes and load due to hydrogen low volumetric energy density. Other authors suggested the use of LNG as a hydrogen carrier for onboard power generation with fuel cells. This system may have a further advantage for pleasure boats due to low acoustic impact and low pollutant emissions. However, the fuel cell operation at part-load conditions may be difficult due to the methane reformer [14]. This study investigates several combinations of onboard power generation units and Li-Ion battery storage, and it is a preliminary techno-economical evaluation of such hybrid solutions.

\section{Case study}

The analysis is focused on a $50 \mathrm{~m}$ yacht, manufactured by Sanlorenzo spa, which is currently equipped with $2118 \mathrm{~kW}$ e diesel generators, which are fully dedicated to coverthe hotel services. The onboard installed electric loads amount to a total of more than $700 \mathrm{~kW}$ but they are never activated simultaneously.

Electrical consumption was monitored from 6/7/2018 to $1 / 10 / 2018$ with a 30 seconds time resolution (Figure 2), resampled to 5 minutes for this study, and with $1 \mathrm{~kW}$ resolution. The minimum load $(18.5 \mathrm{~kW})$, the average load $(64.4 \mathrm{~kW})$, the maximum load $(128.2 \mathrm{~kW})$ and the average daily consumption $\left(1.55 \cdot 10^{3} \mathrm{kWh}\right)$ are calculated from the load data. The analyses in this study are carried out by assuming two different usage scenarios. The first scenario considers an annual operating period of 87 days ( 3 months), whereas the second one considers a more extended usage, i.e. 261 days ( 9 months) per year. In the second scenario, the loads for the first three months are repeated for the next six. The entire system lifetime was assumed to be equal to 10 years.

By taking into account the energy requirements, aesthetic constraints and limited space available on the yacht, Lithium-Ion batteries and PEMFC are selected. For the PEMFC power supply, the use of LNG as a hydrogen carrier is considered. LNG is converted into $\mathrm{H}_{2}$ and $\mathrm{CO}_{2}$ through a Steam Methane Reforming (SMR) reactor. Therefore, the fuel cell system (FCS) includes the SMR and the PEM fuel cell itself.

The first configuration studied is the 'base case' configuration, which reproduces the generation system currently used on the yacht. In this case, the load is entirely covered by the diesel generator set.

The second configuration is a hybrid genset configuration with a battery. In this case, the load is satisfied by both the genset and the batteries. These are recharged when the load is lower than the genset nominal power, and they are discharged otherwise.

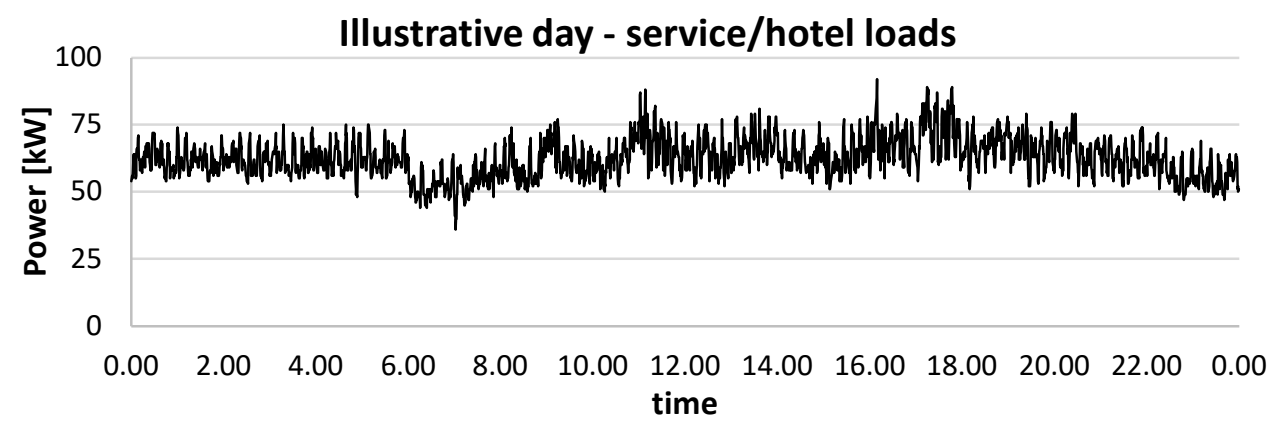

Fig. 2. Service/hotel loads of an illustrative day, 30 seconds resolution. 
Finally, a hybrid genset-battery-FC configuration was considered (Figure 3). In this case, the PEMFC provides a base load equal to $\mathrm{P}_{\mathrm{fc}, \mathrm{AC}}$, while the genset and batteries supply the additional energy needed to satisfy the load, with a logic similar to the previous configuration.

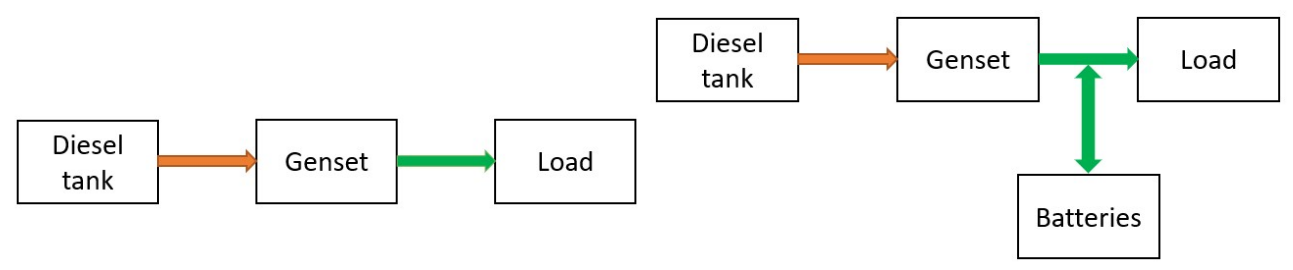

(a)

(b)

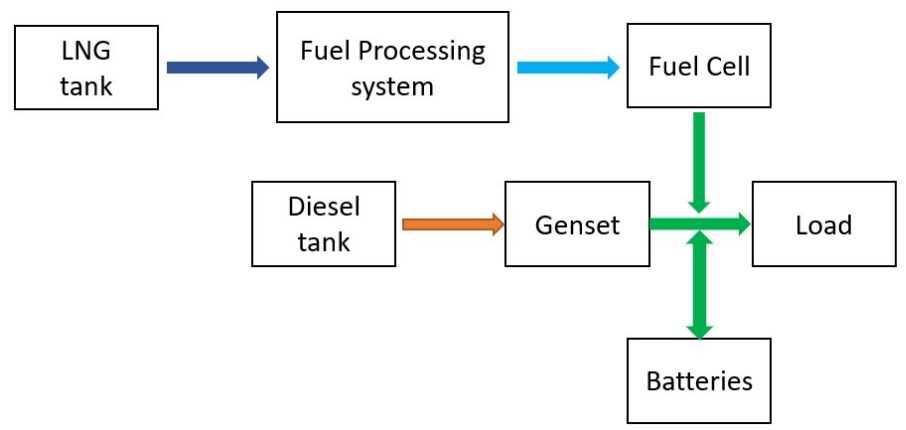

(c)

Fig. 3. a) Base case configuration diagram; b) Hybrid genset-batteries configuration diagram; c) Hybrid genset-batteries-FC configuration diagram.

Regarding the sizing of each component:

- the nominal capacity of the batteries $\left(\mathrm{C}_{\mathrm{st}}\right)$ is varied with a step of $25 \mathrm{kWh}$, from 0 $k W h$ to $1000 \mathrm{kWh}$ for all the simulated configurations;

- $\quad$ A PEMFC with $\mathrm{P}_{\mathrm{fc}, 1}$ in DC of $21 \mathrm{~kW}$ produced by the Ballard Power System [15] associated with an SMR reactor patented by Tokyo Gas [16] is adopted. In addition, each configuration including the fuel cell system is also analyzed considering two FCs achieving a $\mathrm{P}_{\mathrm{fc}, 2}$ of $42 \mathrm{~kW}$;

- The size of the diesel generator $\left(\mathrm{P}_{\mathrm{g}}\right)$ for the base case is $130 k W_{e}$. In the configurations including the battery storage system, the generator size was varied with steps of $1 k W_{e}$ by considering a minimum and maximum power corresponding to the average and maximum load respectively.

All the configurations are analyzed in a standard operation mode and in a modified operation mode in which a so-called 'Full Electric' phase (FE phase) is present. This operation mode consists of six, or eight, hours per day in which the load is satisfied without using the diesel genset. A FE phase is introduced in the study as it reduces the noise and environmental emissions. Therefore, a FE phase is an attractive operating mode for pleasure boats, and it could represent a key advantage of hybrid systems over the traditional ones. Since diesel genset is turned down in the FE phase, the load is entirely powered by the batteries and by the FC, if present. During the non-FE phase, the system follows the same operating logic as before: the load is satisfied simultaneously by the genset, batteries and FC.

Two alternative FE phase configurations have been studied. A period of six hours from 10:00 am to 04:00 pm and a more extended period of eight hours, during the night, from 11:00 pm to $07: 00 \mathrm{am}$. 


\section{Methodology}

\section{Fuel consumption}

Diesel consumption is calculated according to the specific consumption for different loads of the actual generator set currently installed in the yacht (minimum fuel consumption of $225 \mathrm{~g} / \mathrm{kWh}$ at full load). Natural gas consumption is determined through Eq. (1) with the efficiency $(\eta)$ for the entire fuel cell system set to 0.39 [17]. This value is the product of SMR, PEMFC and power conversion system (PCS) efficiencies, which are assumed equal to 0.8 , 0.5 and 0.97 respectively.

$$
\dot{m}_{N G}=\frac{P_{f c, A C}}{\eta \cdot L H V_{N G}}
$$

\section{Emissions}

The annual diesel genset $\mathrm{CO}_{2}$ emissions are calculated from the diesel consumption with an emission factor equal to $3.2 \mathrm{~kg}$ of $\mathrm{CO}_{2}$ per $\mathrm{kg}$ of diesel [18]. The $\mathrm{FCS} \mathrm{CO}_{2}$ emissions, due to the fuel processing system, are estimated with an emission factor of $0.56 \mathrm{~kg}$ of CO2 per $\mathrm{kWh}$ of produced electricity [19]. Finally, the genset $\mathrm{NO}_{\mathrm{x}}$ emissions are estimated by considering a $\mathrm{NO}_{\mathrm{x}}$ emission factor of $2 \mathrm{~g}$ per each $\mathrm{kWh}$ of produced electricity [20], while $\mathrm{FCS} \mathrm{NO}_{\mathrm{x}}$ emissions can be assumed as negligible.

\section{Volume and mass footprint}

The estimation of battery volume and mass is based on the assumption of a battery volumetric and gravimetric energy densities of $600 \mathrm{Wh} / \mathrm{l}$ and $230 \mathrm{Wh} / \mathrm{kg}$ respectively [21], which are representative of the most promising lithium-ion battery technologies. For a preliminary estimate of FCS volume, the method proposed in [16] is adopted. Hence, the total system volume is assumed to be around six times the sum of the stack volume $\left(0.014 \mathrm{~m}^{3}\right)$ and the reforming reactor volume, equal to $0.04 \mathrm{~m}^{3}$. The mass of the FCS is assumed to be around $180 \mathrm{~kg}$. Such a value derives from the sum of the PEMFC without refrigerant (17 kg [15]), the auxiliary components assumed on the basis of other existing systems (60 kg [22]) and the SMR reactor considered to be built of $30 \%$ (in volume) with steel (about $100 \mathrm{~kg}$ ). However, to maintain a conservative analysis, the whole system volume and mass are assumed of $1 \mathrm{~m}^{3}$ and $500 \mathrm{~kg}$, respectively. Finally, the LNG cryogenic storage tanks are designed to guarantee at least 15 days of autonomy.

\section{Operating lifetime}

Battery accumulates damage due to a continuous cyclic operation that shortens the battery lifespan and may lead to a frequent replacement. Battery damaging accumulation is modelled with a cycle-life curve approach, in which the battery capacity loss is calculated from the number of charge/discharge cycles and depth [23]. The cycle-life curve parameters are taken from the literature, and the cycle number and depth are determined with a Rainflow Counting algorithm [23-24]. Inverters lifetime, in accordance with the standard assumptions, is assumed to be ten years. Finally, to maintain a conservative analysis, the lifetime of the PEMFC is assumed to be $20000 h$, by considering a stationary utilization under realistic operating conditions (impurities in fuel and air, humidity, aggressiveness of marine environment, etc.). This value is estimated by halving the commonly assumed lifetime of a PEMFC for a stationary use $(40000 h[25])$.

\section{Costs}

The economic analysis is based on three indicators: 
- fuel cost: annual cost for fuel purchasing. Diesel and LNG prices are assumed as $1.40 € / l$ and $1.00 € / \mathrm{kg}$, respectively;

- $\quad \operatorname{CAPEX}$ (Capital Expenditure): The cost of the diesel generator $\left(\mathrm{C}_{\mathrm{g}}\right)$ is obtained from the cost of three generators of different sizes supplied by the yacht manufacturer $(\epsilon$ 40000 for a nominal power of $60 \mathrm{~kW}, € 54500$ for $118 \mathrm{~kW}$ and $€ 56500$ for $150 \mathrm{~kW}$ ). The battery cost is based on the cost of current lithium-ion batteries for automotive applications. Therefore, the PCS costs are assumed to be $190 € / k W h$ [26-27] and $230 € / \mathrm{kW}$ [28], respectively. The cost of the LNG cryogenic tank is assumed as $15500 € / \mathrm{m}^{3}$ [29], and the cost of the fuel cell system is estimated as $2000 € / \mathrm{kW}$ [16].

- $\quad C A$ (Cost Analysis): annualized costs including the operation and maintenance costs $\left(\mathrm{C}_{\mathrm{o} \& \mathrm{~m}}\right)$, annualized capital costs $\left(\mathrm{C}_{\mathrm{cap}}\right)$, calculated through the Capital Recovery Factor (CRF), and system component replacement costs $\left(\mathrm{C}_{\mathrm{rep}}\right)$, which are discounted and annualized as well.

Table 1. Summary table of the values assumed in the text

\begin{tabular}{|c|c|c|c|}
\hline \multicolumn{2}{|l|}{ BATTERY SYSTEM } & \multicolumn{2}{|l|}{ FUEL CELL SYSTEM } \\
\hline Charge efficiency & 0.95 & Fuel processor efficiency & 0.8 \\
\hline Discharge efficiency & 0.95 & Fuel cell stack efficiency & 0.5 \\
\hline Gravimetric energy density & $230 \mathrm{Wh} / \mathrm{kg}$ & Inverter efficiency & 0.97 \\
\hline Volumetric energy density & $600 \mathrm{Wh} / \mathrm{l}$ & $\begin{array}{ll}\text { Gravimetric } \\
\text { density }\end{array}$ & $42 \mathrm{~W} / \mathrm{kg}$ \\
\hline Maximum lifetime battery & 10 years & $\begin{array}{ll}\begin{array}{l}\text { Volumetric } \\
\text { density }\end{array} & \text { power } \\
\end{array}$ & $21 \mathrm{~W} / 1$ \\
\hline Maximum lifetime PCS & 10 years & Lifetime & $20000 \mathrm{~h}$ \\
\hline Cost of battery & $190 € / \mathrm{kWh}$ & Fuel cell volume & $0.014 \mathrm{~m}^{3}$ \\
\hline Cost of PCS & $230 € / \mathrm{kW}$ & SMR volume & $0.04 \mathrm{~m}^{3}$ \\
\hline \multirow[t]{2}{*}{ Replacement cost of battery } & $95 € / \mathrm{kWh}$ & Cost of fuel cell system & $2200 € / \mathrm{kW}$ \\
\hline & & Cost of LNG tank & $15500 € / \mathrm{m}^{3}$ \\
\hline \multicolumn{2}{|l|}{ FUELS } & \multicolumn{2}{|l|}{ EMISSION FACTORS } \\
\hline Density of diesel & $0.840 \mathrm{~kg} / \mathrm{l}$ & $\mathrm{CO}_{2}$ genset & $3.2 \mathrm{kgCO}_{2} / \mathrm{kgdiesel}$ \\
\hline Density of LNG & $0.450 \mathrm{~kg} / \mathrm{l}$ & $\mathrm{CO}_{2}$ fuel cell processor & $0.56 \mathrm{kgCO}_{2} / \mathrm{kWh}$ \\
\hline Diesel price & $1.4 € / 1$ & NOx genset & $0.002 \mathrm{kgNO}_{\mathrm{x}} / \mathrm{kWh}$ \\
\hline LNG price & $1 € / \mathrm{kg}$ & NO $_{x}$ fuel cell processor & negligible \\
\hline
\end{tabular}

\section{Power and Energy Management System (PEMS)}

A PEMS was modelled and studied in MATLAB environment [30]. This model receives in input the nominal power of the genset $\left(\mathrm{P}_{\mathrm{g}}\right)$, the nominal battery capacity $\left(\mathrm{C}_{\mathrm{st}}\right)$ and other storage technical parameters. These are charge $\left(\eta_{c}\right)$ and discharge $\left(\eta_{d}\right)$ efficiency, both considered equal to 0.95 , battery charge and discharge power ratings $\left(\mathrm{P}_{\mathrm{st}}\right)$, assumed to be enough to charge and discharge the storage capacity in $1 h$, and battery minimum and maximum SoC (State of Charge), assumed as 0.2 and 0.95 , respectively. In addition to these parameters, the simulated time period ( 3 or 9 months), the load L required by the yacht at each $i$-th timestep and the FCS nominal power $\left(\mathrm{P}_{\mathrm{fc}, \mathrm{AC}}\right)$ must be specified as well.

Once the listed values are set, the whole system is simulated. The PEMS is managed to satisfy the load in each time step by prioritizing the diesel generator full-load operation and adjusting the production by charging, or discharging, the battery, if needed.

If the difference between the required load and the power supplied by the generation systems is not zero, it is necessary to charge or discharge the storage. Then: 


$$
\begin{aligned}
\operatorname{SoC}_{i} & =\operatorname{SoC}_{i-1}-\min \left[\left(L_{i}-P\right) \Delta \mathrm{t} ;\left(\mathrm{SoC}_{i-1}-\mathrm{SoC}_{m i n}\right) \frac{C_{s t}}{\eta_{d}} ; \mathrm{P}_{d} \Delta \mathrm{t}\right] \frac{\eta_{d}}{C_{s t}} \\
\left(\mathrm{~L}_{\mathrm{i}}-\mathrm{P}\right)>0 & : \\
\operatorname{SoC}_{i} & =\operatorname{SoC}_{i-1}+\min \left[\left(P-L_{i}\right) \Delta \mathrm{t} ;\left(\mathrm{SoC}_{\max }-\mathrm{SoC}_{i-1}\right) \frac{C_{s t}}{\eta_{c}} ; \mathrm{P}_{c} \Delta \mathrm{t}\right] \frac{\eta_{c}}{C_{s t}} \\
\left(\mathrm{~L}_{\mathrm{i}}-\mathrm{P}\right)<0 & :
\end{aligned}
$$

where $\mathrm{P}$ is equal to $\mathrm{P}_{\mathrm{g}}$, for configurations without the FCS, or it is equal to the sum of $\mathrm{P}_{\mathrm{g}}$ and $\mathrm{P}_{\mathrm{fc}, \mathrm{AC}}$, otherwise.

This battery management strategy ensures the best results in terms of efficiency, because the diesel engine efficiency is monotonically increasing with the load (at full load it has the best efficiency).

However, the configurations that also include a FE phase may require two slightly different management strategies: one for the FE period and the other for the non-FE period (Figure 4). The production modes and the related management strategies are switched together at the initial $\left(\mathrm{t}_{\mathrm{in}}\right)$ and final $\left(\mathrm{t}_{\mathrm{fin}}\right)$ instants of the FE phase.

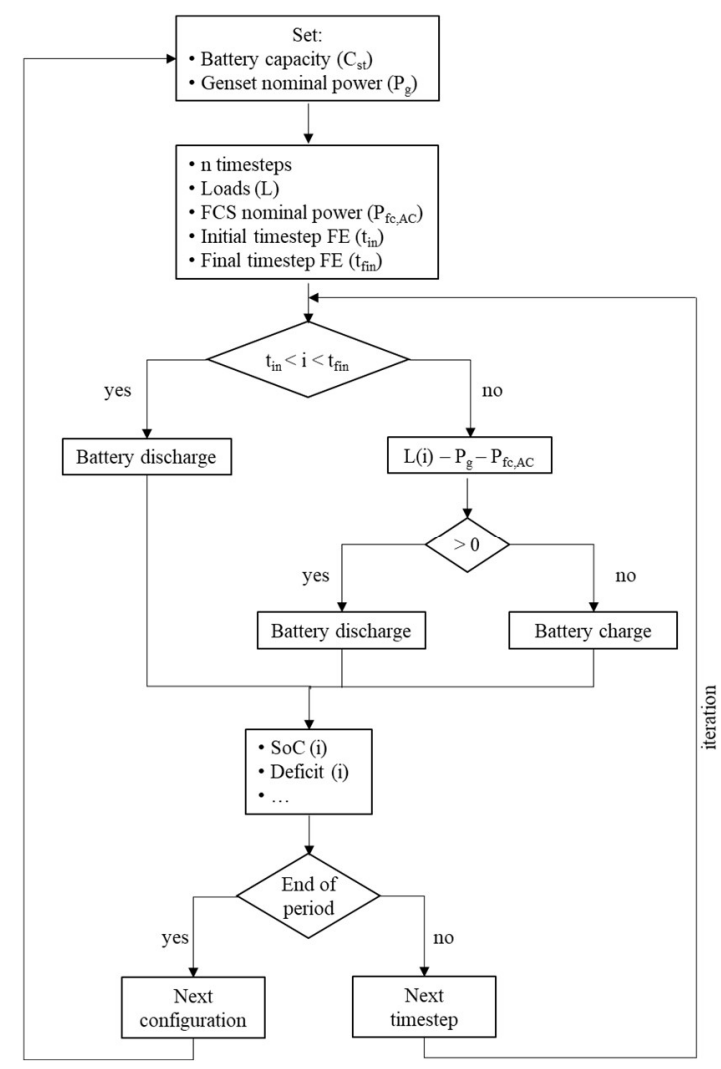

Fig. 4. Representation of the management logic for the genset-battery-FC configuration with the FE phase

Selecting the best combination of genset nominal power $\left(\mathrm{P}_{\mathrm{g}}\right)$ and nominal battery capacity $\left(\mathrm{C}_{\mathrm{st}}\right)$ for each configuration allows for a preliminary system design and a comparison of the different configurations. 
First, without the FE phase, it is required that $100 \%$ of the load is always satisfied. Instead, with the FE phase, it is required that $95 \%$ of the load is satisfied during the FE hours. In such a case, it is assumed that the diesel generator supplies the remaining $5 \%$ of the energy required.

Three performance parameters $\left(\mathrm{CO}_{2}\right.$ emissions, capital cost (CAPEX) and occupied volume (V)) are the most significant and they should be minimized at the same time. Therefore, for each configuration, a Pareto front that collects all the $\left\{\mathrm{C}_{\mathrm{st}}, \mathrm{P}_{\mathrm{g}}\right\}$ combinations that yield the optimal trade-offs between the listed parameters may be constructed. Since all the meaningful $\left\{\mathrm{C}_{\mathrm{st}}, \mathrm{P}_{\mathrm{g}}\right\}$ combinations have been already simulated, the Pareto fronts may be directly constructed from the available data, without a further optimization step being required. Finally, some weights are associated with each objective such that only one $\left\{\mathrm{C}_{\mathrm{st}}, \mathrm{P}_{\mathrm{g}}\right\}$ combination is selected from the Pareto front. This selection was performed through a decision criterion named TOPSIS [31]. The $\left\{\mathrm{C}_{\mathrm{st}}, \mathrm{P}_{\mathrm{g}}\right\}$ combination selected in this way, is the one that most accurately represents the objective hierarchy specified by the weights. The assumed objective weights are $0.5,0.3$ and 0.2 , for the volume, the emissions and the CAPEX, respectively. Such a hierarchy of objectives is defined to prioritize the minimization of the occupied volume, which is very costly in marine applications, over the minimization of $\mathrm{CO}_{2}$ emissions and the CAPEX, i.e. the least essential indicators in pleasure boats.

\section{Results}

The results reported in this section are related to the three months per year utilization scenario. For the brevity sake, only the most significant results $\left(\mathrm{CO}_{2}\right.$ and CAPEX emissions) are reported. The results related to the best solution for each configuration, determined as specified in section 3.2, are shown in Table 1 and Fig. 8a, $8 \mathrm{~b} 8 \mathrm{c}$. The results related to the reference configuration (base case) show that the diesel genset emits about $100 t$ of $\mathrm{CO}_{2}$ and $269 \mathrm{~kg}$ of $\mathrm{NO}_{\mathrm{x}}$ during the entire operating period. On the other hand, with the hybrid gensetbattery system, it is possible to reduce the size of the diesel generator and obtain a slight reduction in $\mathrm{CO}_{2}$ emissions, compared to the base case configuration.

The adoption of a FE phase for this hybrid system shows that the battery capacity must be increased up to about $600 \mathrm{kWh}$ and $700 \mathrm{kWh}$ to obtain 6 and 8 hours of FE, respectively. Therefore, this setup brings an increase in capital costs and size, and it yields a reduction of $\mathrm{CO}_{2}$ emissions only of a few percentage points. Figure $5 \mathrm{a}$ and $5 \mathrm{~b}$ show the CAPEX and $\mathrm{CO}_{2}$ emissions trends. Each graph is divided into two zones by a red dotted threshold: in the lower zone, a full satisfaction of the load during the non-FE phase is not possible, whereas in the upper zone it is possible to satisfy the load for any given operating condition. The black thresholds represent the configurations that allow the load to be satisfied during the FE phase at $90 \%, 95 \%$ and $99 \%$, respectively.

With hybrid diesel-battery-FC configurations, it is possible to reduce the size of both the diesel generator and the battery, in comparison to the system with only batteries, still ensuring the full coverage of the load. Moreover, the FC integration allows for a reduction in fuel cost and $\mathrm{CO}_{2}$ and $\mathrm{NO}_{\mathrm{x}}$ emissions of $10 \%$ and $33 \%$, respectively. The $42 \mathrm{~kW} \mathrm{FC}$ leads to a reduction of $\mathrm{CO}_{2}$ and $\mathrm{NO}_{x}$ emissions by $16 \%$ and $64 \%$ respectively.

The adoption of a fuel cell system leads to an increase in capital costs and overall size. The volume of cryogenic tanks, which is necessary to guarantee 15 sailing days, exceeds $3 \mathrm{~m}^{3}$ in the case of a $21 \mathrm{~kW} \mathrm{FC}$ and $6 \mathrm{~m}^{3}$ with a $42 \mathrm{~kW}$ FC. Figures $6(\mathrm{a})$ and $6(\mathrm{~b})$ show the $\mathrm{CO}_{2}$ emissions and CAPEX trends for the genset-battery-FC21 configuration.

The results of the genset-battery-FC configurations with six, or eight, FE hours show that these systems require smaller batteries than other configurations. In the case of a $42 \mathrm{kWFC}$, the required battery capacity is only $225 \mathrm{kWh}$. However, the overall volume of this configuration is $2.4 \mathrm{~m}^{3}$ plus $6.6 \mathrm{~m}^{3}$ of LNG storage.Furthermore, there is a reduction in fuel 
costs and $\mathrm{NO}_{\mathrm{x}}$ and $\mathrm{CO}_{2}$ emissions, in comparison to the base case, approximately equal to that obtained for the case without a FE phase. Figures 7(a) and 7(b) show the trends for $\mathrm{CO}_{2}$ emissions and CAPEX for the genset-battery-FC42 configuration with an eight-hour FE phase.

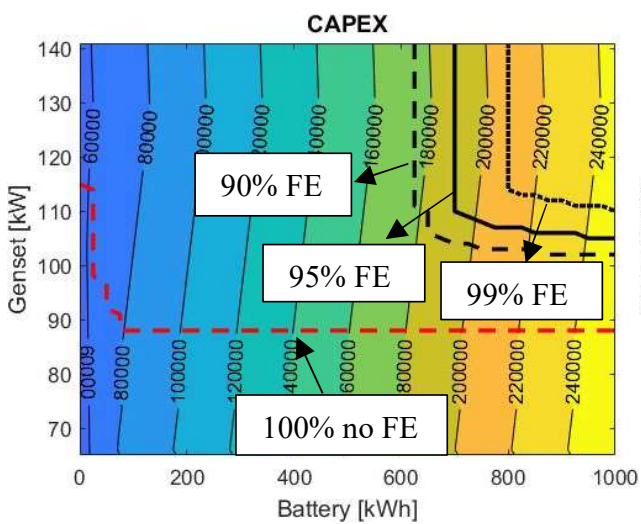

(a)

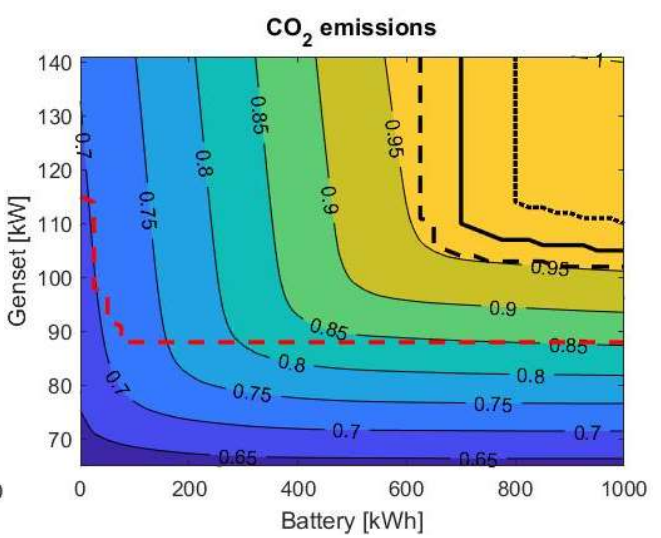

(b)

Fig. 5. a) CAPEX in $€$ for the genset-battery $8 \mathrm{hFE}$ configuration - b) $\mathrm{CO}_{2}$ emissions for the gensetbattery $8 \mathrm{hFE}$ configuration evaluated as the ratio between the mass of $\mathrm{CO}_{2}$ emitted compared to the mass of $\mathrm{CO}_{2}$ emitted in the base case configuration

Since the FCS efficiency is comparable to that of ICE , the consumption and emission reduction is related to the fuel change, rather than to the different energy conversion devices. For this reason, a more 'market-ready' solution with a dual-fuel genset (diesel-LNG) is briefly evaluated. By keeping the genset and battery sizes equal to those determined for the hybrid genset-battery system and by replacing the genset with a dual-fuel type, there is a $20 \%$ reduction in $\mathrm{CO}_{2}$ emissions [18] and $40 \%$ costs for fuel purchase compared to the base case configuration. Besides, the dual-fuel genset CAPEX, estimated by increasing the diesel genset cost of $20 \%$, plus that of batteries and cryogenic tanks $\left(10 \mathrm{~m}^{3}\right.$ for 15 days of autonomy), is approximately equal to that of the configuration with genset, battery and a 42 $k W \mathrm{FC}$.

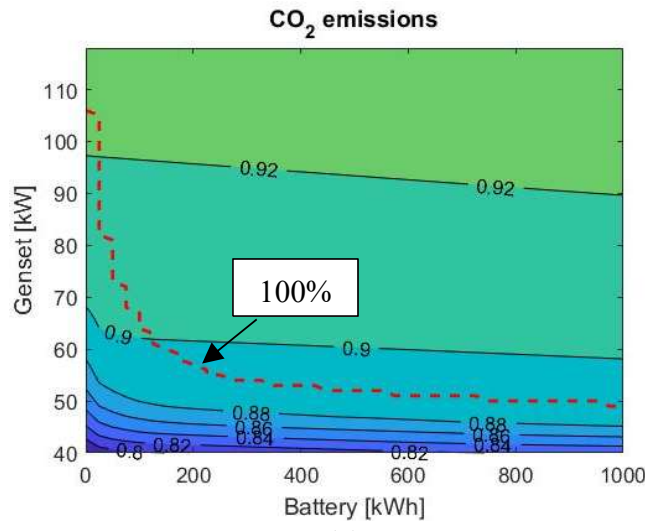

(a)

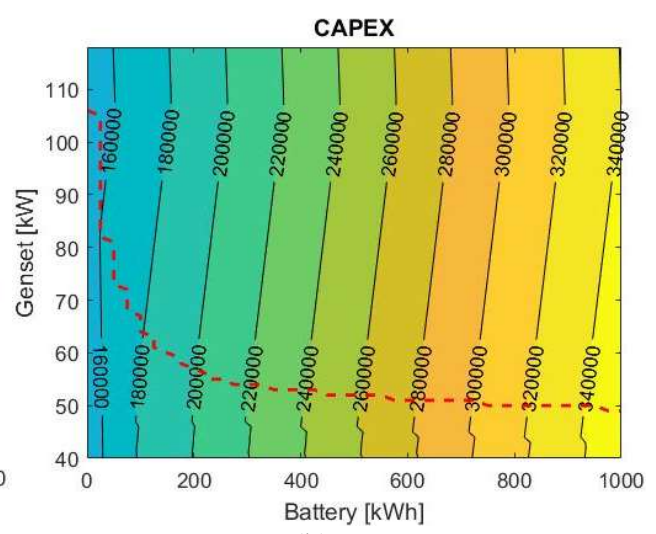

(b)

Fig. 6. a) $\mathrm{CO}_{2}$ emissions for the genset-battery-FC21 configuration evaluated as the ratio between the mass of $\mathrm{CO}_{2}$ emitted compared to the mass of $\mathrm{CO}_{2}$ emitted in the base case configuration - b) CAPEX in $€$ for the genset-battery-FC21 configuration 


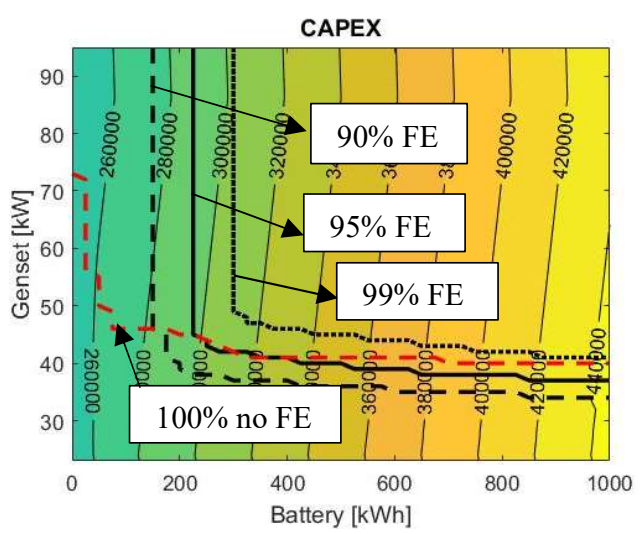

(a)

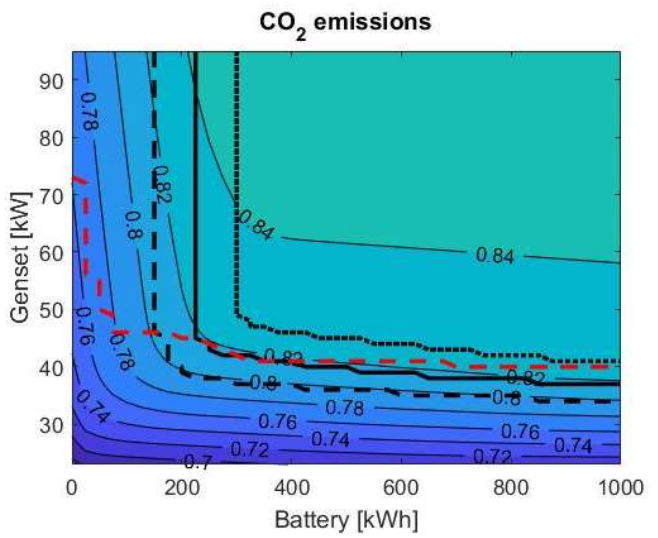

(b)

Fig. 7. a) $\mathrm{CO}_{2}$ emissions for the genset-battery-FC42 $8 \mathrm{hFE}$ configuration evaluated as the ratio between the mass of $\mathrm{CO}_{2}$ emitted compared to the mass of $\mathrm{CO} 2$ emitted in the base case configuration $-b$ ) CAPEX in $€$ for the genset-battery-FC42 8hFE configuration

Table 2. Sizes of components for each configuration

\begin{tabular}{|c|c|c|c|c|c|c|c|c|c|c|}
\hline & $\begin{array}{l}\text { Base } \\
\text { case }\end{array}$ & $\begin{array}{l}\text { Genset- } \\
\text { Battery }\end{array}$ & $\begin{array}{c}\text { Genset- } \\
\text { Battery } \\
\text { 6hFE }\end{array}$ & $\begin{array}{l}\text { Genset- } \\
\text { Battery } \\
\text { 8hFE }\end{array}$ & $\begin{array}{c}\text { Genset- } \\
\text { Battery } \\
\text { FC 21 }\end{array}$ & \begin{tabular}{|c|} 
Genset- \\
Battery \\
FC 21 \\
6hFE \\
\end{tabular} & \begin{tabular}{|c|} 
Genset- \\
Battery \\
FC 21 \\
8hFE \\
\end{tabular} & $\begin{array}{l}\text { Genset- } \\
\text { Battery } \\
\text { FC 42 }\end{array}$ & \begin{tabular}{|c|} 
Genset- \\
Battery \\
FC 42 \\
6hFE \\
\end{tabular} & \begin{tabular}{|c|} 
Genset- \\
Battery \\
FC 42 \\
8hFE \\
\end{tabular} \\
\hline Genset [kW] & 130 & 82 & 98 & 110 & 68 & 75 & 75 & 52 & 54 & 50 \\
\hline Battery [kWh] & - & 125 & 600 & 700 & 75 & 425 & 475 & 50 & 225 & 225 \\
\hline Fuel cell [kW] & - & - & - & - & 21 & 21 & 21 & 42 & 42 & 42 \\
\hline
\end{tabular}

The analyses for the use of the yacht for nine months per year brought to the following results:

- the annual expenditure for the purchase of fuel triples as the genset and the fuel cell system delivers three times the energy supplied in three months;

- $\mathrm{CO}_{2}$ and $\mathrm{NO}_{\mathrm{x}}$ emissions on an annual basis triple; however, the percentage reduction in emissions compared to the base case configuration remains unchanged;

- the CA undergoes an increase due to the increase in the $\mathrm{C}_{\mathrm{rep}}$ item. Due to the greater annual use of batteries and the fuel cells, it is necessary to replace them a larger number of times.

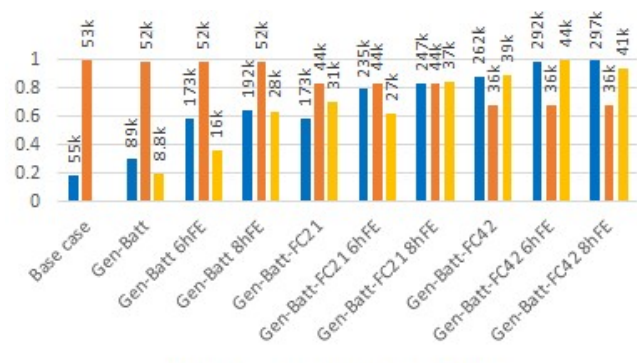

mCAPEX [€] $=$ Fuel costs [£] $=\mathrm{CA}[€]$

(a)

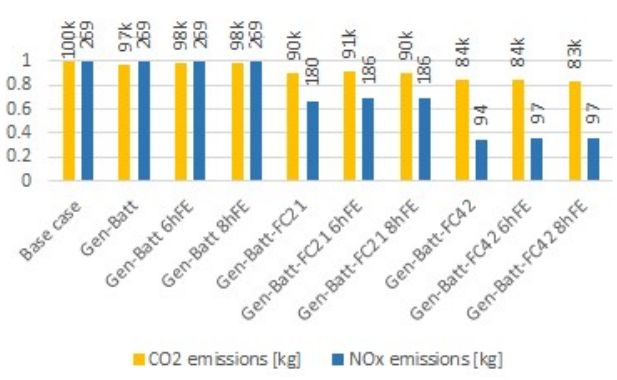

(b) 


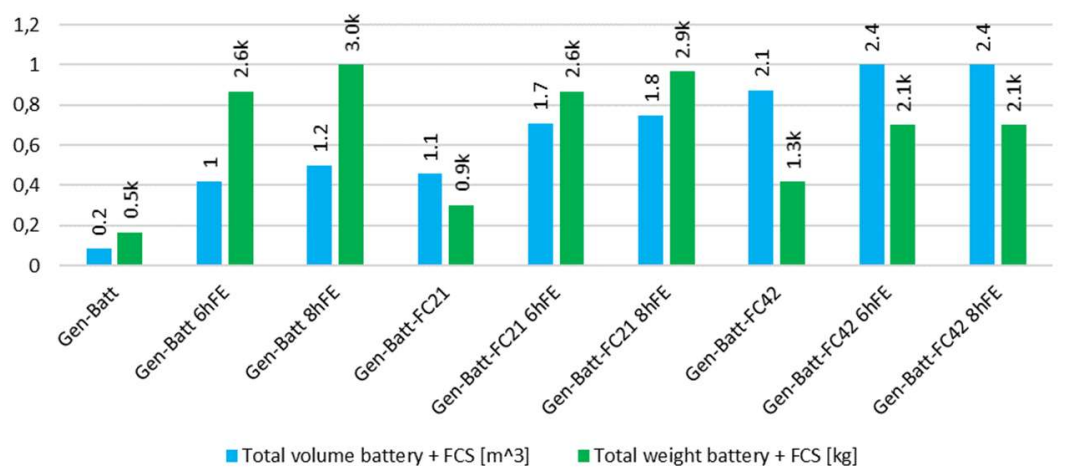

(c)

Fig. 8. Comparison of the results for the optimal generator-battery combinations for each configuration. (normalized to the maximum value).

\section{Conclusions}

The study showed that the battery and diesel-generator integration lead to an ICE downsizing and a small emissions reduction. The battery capacity required for the case with eight FE hours per day is $700 \mathrm{kWh}$ for a total volume of $1.2 \mathrm{~m}^{3}$. On the other hand, the fuel cell had a substantial impact in terms of battery and diesel generator size reduction. The $\mathrm{CO}_{2}$ emissions are reduced by $10 \%$ and $16 \%$ for the $21 \mathrm{~kW} \mathrm{FC}$ and $42 \mathrm{~kW} \mathrm{FC}$, respectively. However, the overall volume and cost of such systems are higher than that of the battery configuration. With the FE phase, smaller batteries and diesel generators could be adopted. However, the total volume of this configuration is over $2 \mathrm{~m}^{3}$ for the $42 \mathrm{~kW} \mathrm{FC}$.

For an annual utilization of nine months, there are no substantial differences and the annual consumption and emissions triple, while the $\mathrm{CA}$ increases due to a faster component ageing. Since the FCS efficiency is comparable to the ICE one, the emission and consumption reduction are more linked to the fuel change than to the energy conversion devices. With a hybrid dual fuel-battery generator system, a more straightforward and commercially available solution is pursued. In this case, roughly the same $\mathrm{CO}_{2}$ emission reduction is achieved with a capital cost and volume similar to generator-battery-FC42 configuration. In the future, fossil LNG could be replaced by renewable fuels. For instance, the use of bioLNG from anaerobic biomass digestion processes, or synthetic LNG from the electrolysis of renewable electricity and methanation, could make the investigated generation system carbon neutral.

\section{References}

1. IMO, 2017b. URL http://www.imo.org/en/OurWork/Environment/Pollution Prevention /AirPollution/Pages/Air-Pollution.aspx

2. Marine Environment Protection Committee (MEPC), 74th session, 13-17 May 2019 http://www.imo.org/en/MediaCentre/MeetingSummaries/MEPC/Pages/MEPC-74thsession.aspx

3. S. Barsali, R. Giglioli, P. Pelacchi, D. Poli. Hybrid energy systems for static applications. In: 2016 IEEE AEIT international annual conference - sustainable development in the mediterranean area, Capri, Italy; 2016.

4. M. Ceraolo, M. Funaioli, G. Lutzemberger, M. Pasquali, D. Poli, L. Sani, Electrical storage for the enhancement of energy and cost efficiency of urban railroad systems, Civil-Comp. Proc. 104 (2014) 
5. M.U. Mutarraf, Y. Terriche; K.A.K. Niazi; J.C. Vasquez; J.M. Guerrero, Energy Storage Systems for Shipboard Microgrids-A Review. Energies 2018, 11, 3492

6. B. Curt, Marine transportation of LNG, presentation at the Intertanko conference March 29, 2004.

7. A.B. Smith, Gas fuelled ships: fundamentals, benefits classification \& operational issues. In: Proceedings of the first gas fuelled ships conference, Hamburg, Germany 2010.

8. O. Schinas, M. Butler Feasibility and commercial considerations of LNG-fueled ships. Ocean Engineering Volume 122, 1 August 2016, Pages 84-96

9. G.A. Livanos, G. Theotokatos., D.N. Pagonis, Techno-economic investigation of alternative propulsion plants for ferries and roro ships. Energy Conversion Management 79,640-651. 2014.

10. G. Pasini, A. Baccioli, L. Ferrari, U. Desideri. Potential energy recovery from LNG regasification in LNG-fueled ships. E3S Web of Conferences, 113, p.02011. 2019.

11. B. Zahedi, L. Norum, K. Ludvigsen. Optimized efficiency of all-electric ships by dc hybrid power systems. Journal of Power Sources, 255, pp.341-354. 2014.

12. T.Tronstad, H. Astrand, G. Haugom e L. Langfeldt, "Study on the use of fuel cells in shipping. DNV-GL. Study commissioned by European Maritime Safety Agency (EMSA), 2017.

13. Pathways to sustainable shipping - American Bureau of Shipping

14. U. Desideri, R. Giglioli, G. Lutzemberger, G. Pasini and D. Poli, "Auxiliary Power Units for pleasure boats," 2017 6th International Conference on Clean Electrical Power (ICCEP), Santa Margherita Ligure, 2017, pp. 650-655

15. Ballard Power System, Scheda tecnica cella a combustibile FCvelocity-9ssl. URL https://www.ballard.com/docs/default-source/motive-modules-documents/materialhandling/ fcvelocity-9ssl.pdf.

16. B. D. James e D. A. DeSantis, "Manufacturing Cost and Installed Price Analysis of Stationary Fuel Cell Systems," Strateg. Anal., pp. 1-143, 2015.

17. A. L. Dicks e D. A. Rand, "Fuel cell systems explained," John Wiley \& Sons Ltd, 2018.

18. IMO, "Guidelines on the method of calculation of the attained energy efficiency design index for new ships," 2017.

19. P. Sun et al., "Criteria Air Pollutants and Greenhouse Gas Emissions from Hydrogen Production in U.S. Steam Methane Reforming Facilities," Environ. Sci. Technol., pp. 7103-7113, 2019.

20. T. R. Walker, "Green Marine: An environmental program to establish sustainability in marine transportation,” Mar. Pollut. Bull., pp. 199-207, 2016.

21. M. Aneke e M. Wang, "Energy storage technologies and real life applications - A state of the art review," Appl. Energy, pp. 350-377, 2016.

22. ProtonMotor.URL http://www.hydrogendays.cz/2016/admin/scripts/source/presentations.

23. MJE Alam, TK Saha. Cycle-life degradation assessment of Battery Energy Storage Systems caused by solar PV variability. 2016 IEEE Power Energy Soc Gen Meet 2016:1-5. https://doi.org/10.1109/PESGM.2016.7741532.

24. G.F. Frate, P.P. Carro, L. Ferrari, U. Desideri. Techno-economic sizing of a battery energy storage coupled to a wind farm: An Italian case study. Energy Procedia, vol. 148, Elsevier; 2018, p. 447-54. https://doi.org/10.1016/j.egypro.2018.08.119.

25. F. A. de Bruijin, G. Janssen (2019). PEM Fuel Cell Materials: Costs, Performance, and Durability. In Fuel Cells and Hydrogen Production (Issue June 2012).

26. I. Tsiropoulos, D. Tarvydas, e N. Lebedeva, "Li-ion batteries for mobility and stationary storage applications," JCR science for policy report, 2018. 
27. BloombergNEF. URL https://about.bnef.com/behind-scenes-take-lithium-ion-batteryprices/.

28. K. Mongird et al., "Energy storage technology and cost characterization report," Pacific Northwest Natl. Lab., pp. 1-120, 2019.

29. E. Jafarzadeh, "LNG-fuelled fishing vessels: a systems engineering approach," Transportation Research Part D: Transport and Environment, 2017.

30. The MathWorks, Inc. MATLAB, 1994-2019. URL mathworks.com/products/matlab.

31. C-L Hwang, Y-J Lai, T-Y Liu. A new approach for multiple objective decision making. Comput Oper Res 1993;20:889-99. https://doi.org/10.1016/0305-0548(93)90109-V. 